\title{
Effectiveness of Internal Control, Good Governance, and Ethics on Budgetary Discipline
}

\author{
Siti Choiriah
}

Universitas Mercubuana, Jakarta, Indonesia

DOI: $10.36348 /$ sb.2019.v05i12.017 $\quad$ | Received: 14.12.2019| Accepted: 21.12.2019| Published: 30.12 .2019

*Corresponding author: Siti Choiriah

Email: choiriahsc@mercubuana.ac.id

\section{Abstract}

This study aims to determine the effect of the effectiveness of internal control, good governance and ethics on budgetary discipline. The object of this study is the Supervisor, Corporate Governance Manager, Budget Manager, Internal Auditor, Head of Internal Auditors in companies in the automotive category and automotive spare parts located in the KIIC Industrial Zone, Karawang, West Java. This research was conducted by sending questionnaires to 89 respondents. Therefore, the data analysis used is PLS SEM. The results showed that the effectiveness of internal control variables had a negative but significant effect on budgetary discipline, good governance and ethics had a positive and significant effect on budgetary discipline.

Keywords: effectiveness of internal control, good governance, ethics, budgetary discipline, manufacturing companies.

Copyright @ 2019: This is an open-access article distributed under the terms of the Creative Commons Attribution license which permits unrestricted use, distribution, and reproduction in any medium for non-commercial use (NonCommercial, or CC-BY-NC) provided the original author and source are credited.

\section{Preliminary}

In this globalization era, the business world is growing in increasingly fierce competition. The purpose of companies in increasingly stringent and competitive economic conditions is to obtain maximum profits with company growth in the long run and also to maintain the survival of the company itself according to Choiriah [1]. Meanwhile, according to Nengzih [2] Companies with good governance, management control systems and planning will have an impact on the company's survival.

The budget is an element of the management control system that functions as a planning and control tool so that managers can carry out organizational activities more effectively and efficiently [3]. Wuner [4] suggests that the budget is also a process of management control that involves formal communication and interaction among managers. Hansen Mowen [5] states that the budget can also encourage managers to develop the overall direction of the organization, anticipate problems, and develop policies for the future.

In the process of corporate budget planning, managers must be able to apply discipline in the process. One of the most ideal disciplinary methods to be used in corporate budget planning is budgetary discipline. Budgetary discipline is a principle in budgeting that allows managers to be responsible for budget performance [6]. In its application, managers must make budgetary discipline as order and compliance (obedience) to the rules or guidelines that underlie budgeting [7]. According to Choiriah [8] Comparing the actual with the actual budget is one way to control whether the company can motivate and use its human resources properly.

To increase compliance with budgetary discipline, strong internal control is also needed [9]. Internal control within the company is a process that is influenced by the board of commissioners, managers, and other business unit personnel, which are made to be able to achieve the objectives of internal control with four objectives which include maintaining company assets, ensuring the accuracy and reliability of records and accounting information, encourage efficiency in company operations, and measure compliance with policies and procedures determined by managers [10].

Good and efficient company operational activities are one of the objectives of the governance 
function or good governance that is applied in company performance [7]. Good governance is corporate governance that explains the relationship between various participation in companies that play a role in determining the direction of performance of the company itself [11]. To determine the direction of company performance, it is necessary to make a decision by the manager based on quality company data information.

All actions taken in the company are in accordance with the ethics principles that apply to the extreme and it is the best way to protect and encourage the interests of all stakeholders. According to Berle and Means, [12] establishes corporate governance as an organization, regulation, ownership, and control. Corporate governance has another dimension that it serves and guides to secure the dedication of stakeholders with the aim of functioning of their expertise, knowledge and experience for the use of the organization. In a business environment, ethical means applying the principles of honesty and fairness in relationships with colleagues and customers [13]. Business or corporate ethics is a form of applied ethics or professional ethics that examines ethical principles, and moral or ethical issues that arise in the business environment [14]. This is a general term that covers all ethical-related issues that arise in the context of doing business. Business ethics is defined as rules, standards, codes, or principles that provide guidelines for morally appropriate behavior in managerial decisions relating to corporate operations, and business relations with the community [15].

The phenomenon in this study is the budgetary indiscipline that occurs in manufacturing companies caused by the influence or encouragement that arises from within the managers to commit negative actions. Such as the use of company budgets for unnecessary asset purchases and the use of corporate budgets for personal use.

\section{THEORETICAL FRAMEWORK Effectiveness of Internal Control}

Subkhi and Mohammad [16] states that the comparison is the relationship between results and objectives, which means the purpose and objectives of the outputs and procedures of the organization that achieves the specified goals. While Mardiasmo [17] further states that it needs to succeed, organizations that succeed in achieving goals, organizations succeed in achieving goals, then the organization is said to have run effectively.

The Treadway Commission Sponsoring Committee Organization (COSO) [18] outlines that internal control is a process governed by the board of directors, management, and other members of the body, which facilitates to ensure that what is meant by the division relating to operations, reporting and approval.

According to Reeve et al. [19], internal control is broadly defined as the procedures and processes used by companies to protect company assets, process information accurately, and ensure applicable laws and regulations.

The Committee of Sponsoring Organizations of Treadway Commission (COSO) in Arens [20] suggests five components of internal control namely: control environment, risk assessment, control activities, information and communication and monitoring of internal control

\section{Good governance}

Effendi [21] argues that good governance is a set of systems that regulate and control companies to create added value for stakeholders. Agoes [22] describes that good governance is a set of rules governing relationships between shareholders, management (managers) of the company, creditors, government, employees, and other internal and external stakeholders related to their rights and obligations or in other words a system that regulates and controls the company so as to create added value for all stakeholders.

The Chartered Institute of Public Finance and Accountancy (CIPFA) [23] further states that Good Governance is good governance with integrity that can ensure openness and comprehensive stakeholder involvement and can define outcomes in terms of sustainable economic, social and environmental benefits , determine the interventions needed to optimize the achievement of the expected results and develop the capacity of the entity, including leadership and individual capabilities, manage risk and performance through strong internal control and financial management, implement good practices in transparency, reporting and auditing to provide accountability effective.

The Chartered Institute of Public Finance and Accountancy (CIPFA) [23] proposes five principles of good governance, namely transparency, accountability, responsibility, independence and fairness.

\section{Ethics}

The company explicitly communicates responsibility in terms of ethics and moral responsibility. Examples are codes of ethics, including formulations on matters such as honesty in business transactions, bribery, corruption and transparency according to Frostenson \& Sandstro [24].

There is a need to support organizations in different ways, otherwise they will not know the company's point of view about ethical business 
practices. In particular, it might not know how to act and behave in situations that require ethical considerations. Organizations need to realize that ethical values and principles change over time and vary across contexts. It is therefore important to create processes that contribute to regulating ethical business practices, but there must also be a structure to support staff in their ethical actions and behavior. Ethical performance appraisal is a sub-area of the ethical process in the conceptual framework of corporate and business ethics throughout the organization which is an ethical performance appraisal. According to [25]. The need for organizations to carry out ethical performance evaluations through an appraisal system. Ethical performance assessments must contribute to strengthening the company's efforts to manage and monitor ethical business practices throughout the organization.

According to Hosmer and Kiewitz [26]. Corporate Responsibility and Business Ethics have proposed that fair treatment of all stakeholders will result in a positive organization in a strategic position and financial gain. The difficulty is that there are many problems of measurement and fair direction, resulting in an increase in profits which further enhances the company's performance.

According to Erwin \& Erwin [27] revealed a general relationship between ethical quality and effectiveness of company performance, higher quality is shown by companies that have business ethics, high public perception. Companies that devote certain human and capital resources to develop comprehensive behaviors that are consistent with company values have a more significant impact by having ethical behavior in the organization.

\section{Budgetary Discipline}

Robbins [28] states that discipline is obedience and respect for the rules that apply in organizations. Nicolae [29] states, that the term 'discipline' is behavior that is bound by rules. Whereas Wren [30], interprets that 'discipline' is obedience to the agreement that has been established.

Budgetary discipline according to Horák \& Šmáčková [20] is compliance with law, contracts, and other legal decisions in implementing the use of a legitimate budget. Umar [27] argues that budgetary discipline as order and compliance with the rules or guidelines that underlie budgeting. Whereas Irons [31] states that budgetary discipline is obedience in fulfilling a number of income and expenses and an obedience to the rules and procedures in budgeting. Therefore, budgetary discipline can be concluded as compliance (obedience) to the rules and procedures that underlie the entire budgeting process.

\section{Hypothesis Development \\ Effect of Effectiveness of Internal Control on Budgetary Discipline}

In companies, managers tend to be deliberately involved in budgetary discipline, such as budget misappropriation and other matters. To overcome this problem, strong internal control is needed to create checks and balances in budgeting. Thus, in the end it will improve the budget balance. Budgeting requires control in the form of monitoring that starts from planning, implementation and reporting to be more effective [17].

Internal control is needed in the planning stage to plan activities to be carried out in accordance with the organization's vision and mission. Internal control in budget planning also reviews the failure of the previous year's budget to avoid a repeat of the next budget. Internal control in the implementation phase is needed so that activities are carried out on time, economically, efficiently and effectively in accordance with established procedures. Meanwhile, internal control in the reporting stage (accountability) is needed so that the activities that have been carried out can be reported on time, transparently and in accordance with applicable regulations.

Research from Ramdany and Yadiati [7] states that the effectiveness of internal control has a positive influence on budget discipline within the company.

\section{Based on this theory, the hypothesis can be formulated as follows} $\mathbf{H}_{\mathbf{1}}$ : The effectiveness of internal control has a positive
effect on budgetary discipline

\section{The Effect of Good Governance on Budgetary Discipline}

The main function of good governance is to direct the goals of the organization. In order for the budget to be carried out according to the plan, budgetary discipline requires direction. Tommasi [32] argues that to improve budgetary discipline, it is necessary to increase accountability to those who implement the budget and he also states that the cause of the gap between the budget set and its realization is the lack of accountability within the company.

Budgetary discipline encourages managers in the company to carry out the budget in accordance with the commitments, time and procedures set. Commitment, compliance with time and procedures can only be done if there is integrity, transparency, intervention and responsibility. Therefore, it can be underlined that implementing budgetary discipline requires good governance. 
Research from Ramdany et al. [7], state that good governance has a positive influence on budgetary discipline in companies.

Based on this theory, the hypothesis can be formulated as follows

$\mathbf{H}_{2}$ : Good Governance has a positive effect on budgetary discipline

\section{The Effect of Ehics on Budgetary Discipline}

Corporate governance is a system where the company is directed and controlled. The board of directors is responsible for their corporate governance. The role of shareholders in governance is to appoint directors and auditors and to convince themselves that there is an appropriate governance structure. According to Valentine, Godkin, Lucero, Valentine, \& Godkin [33] who found that ethics in the company was positively related to employee commitment. Thus, in an environment that has more high business ethics employees are more willing and committed to comply with the rules and regulations set in an organization so as to create good corporate governance and enhance the company's reputation. Meanwhile, according to Pfister [34]. Ethics in the company provides support for communication, commitment and competence which are effective drivers of internal control thereby strengthening budgetary discipline.

According to Fraedrich \& Ferrell [25]. The need for organizations to carry out ethical performance evaluations through an appraisal system. Ethical performance assessments must contribute to strengthening the company's efforts to manage and monitor ethical business practices throughout the organization. According to Hosmer and Kiewitz [26], corporate social responsibility and business ethics have proposed that fair treatment of all stakeholders will produce positive organizational results in strategic positions and financial benefits and enhance the company's reputation.

Based on this theory, the hypothesis can be formulated as follows:

$\mathbf{H}_{3}$ : Ethics has a positive effect on budgetary discipline

\section{Research Design and Methods}

This research is classified as causal research. Causal research is a type of research that aims to test the hypothesis about the effect of one or several variables (independent variables) on other variables (the dependent variable). This study examines the effect of the effectiveness of internal control, good governance, and ethics on budgetary discipline.

\section{Data analysis methods used in this study are}

\section{Descriptive Analysis Method}

This method is used to explain the characteristics of the variables of the Effectiveness of Internal Control, Good Governance and Ethics Against Budgetary Discipline

\section{Verification}

This method is used to test the effect of each variable involved in research using the Structural Equation Model (SEM) with the Partial Least Square (PLS) approach. The use of the SEM PLS method is because the measurement model is formed by variables that have reflective indicators. Models in SEM PLS include outer models (measurement models) and inner models (structural models). Source of data used in this study is Primary Data using observation techniques in which the authors collected data with survey techniques in the form of questionnaires to obtain data from individual opinions.

\section{Population and Sample}

Researchers used manufacturing companies in the KIIC Industrial Estate Karawang, West Java to become a population of 30 companies. The sample in this study are managers of the companies mentioned above such as Internal Auditors, Internal Audit Managers, Budget Managers, Good Governance Managers, Corporate Secretary in the company.

\section{Data Validity and Reliability Test Results} Evaluation Based on Measurement Model (Outer Model)

The first step in evaluating the measurement model is to estimate the convergent validity criteria. Convergent validity is knowing the extent to which the measuring instrument is positively correlated with alternative steps of the same construct. By requiring the outer loading indicator to be above 0.708 squared (0.7082) equals 0.50. [35]. Based on estimates with Smart PLS 3.0, the output is as shown in table 5. as follows:

Value of Discriminant Validity and Composite Reliability 
Table-5: Value of Discriminant Validity and Composite Reliability

\begin{tabular}{|c|c|c|c|c|}
\hline \multirow{3}{*}{$\begin{array}{l}\text { Measurement Model } \\
\text { Discriminant Validity }\end{array}$} & \multicolumn{2}{|c|}{ Results } & \multirow{3}{*}{$\begin{array}{l}\text { Critical } \\
\text { Value }\end{array}$} & \multirow{3}{*}{$\begin{array}{c}\text { Model } \\
\text { Evaluation }\end{array}$} \\
\hline & \multicolumn{2}{|c|}{ Measurement Model } & & \\
\hline & Variabel & $A V E$ & & \\
\hline \multirow[b]{5}{*}{ Composite Reliability } & $X_{1}$ & 0,655 & \multirow{4}{*}{$>0,5$} & Valid \\
\hline & $X_{2}$ & 0,522 & & Valid \\
\hline & $X_{3}$ & 0,587 & & Valid \\
\hline & $Y$ & 0,637 & & Valid \\
\hline & Variabel & $\begin{array}{l}\text { Composite } \\
\text { Reliability }\end{array}$ & & \\
\hline & $X_{1}$ & 0,883 & \multirow{4}{*}{$>0,7$} & Valid \\
\hline & $X_{2}$ & 0,948 & & Valid \\
\hline & $X_{3}$ & 0,934 & & Valid \\
\hline & $Y$ & 0,950 & & Valid \\
\hline
\end{tabular}

Source: Author's Processed Data (2019)

[Effectiveness of internal control $\left(X_{1}\right)$, Good governance $\left(X_{2}\right)$, Ethics $\left(X_{3}\right)$ and Budgetary Discipline $(Y)$ ]

From the table it can be concluded that almost all latent constructs meet reliable criteria. This is indicated by the value of composite reliability above 0.70 and AVE (Average Variance Extracted) above 0.5 as stated by Hair [35] in his book which states that the condition of composite reliability value must be above 0.70 or 0.60 if the research is exploratory. Where as the AVE value of 0.5 or higher indicates that, on average, it measures the extent to which the construct explains more than half of the indicator variance.

\section{RSquare Test Results $\left(\mathbf{R}^{2}\right)$}

In this study, $\mathrm{R}$ Square $\left(\mathrm{R}^{2}\right)$ budgetary discipline construct is equal to 0.624 The results of $R$ Square are in accordance with what was stated by [35] in his book where the value of $\mathrm{R}$ Square has a range between 0 and 1 , the higher the value of $\mathrm{R}$ Square , indicating the higher the accuracy of the predictions.

Table-6: R Square Values

\begin{tabular}{|c|c|c|}
\hline & $\boldsymbol{R}$ Square & $\boldsymbol{R}$ Square Adjusted \\
\hline Budgetary_Diiscipline $(Y)$ & 0,624 & 0,611 \\
\hline \multicolumn{2}{|c|}{ Source: Author's Processed Data (2019) }
\end{tabular}

Path Coefficient Test Results

Table-7: Relationships between Variables

\begin{tabular}{|c|c|c|c|c|c|}
\hline & $\begin{array}{l}\text { Original } \\
\text { Sample }(O)\end{array}$ & $\begin{array}{l}\text { Sample } \\
\text { Mean }(M)\end{array}$ & $\begin{array}{l}\text { Standard } \\
\text { Deviation } \\
(\text { STDEV })\end{array}$ & $\begin{array}{c}\text { T Statistics } \\
(|O / S T D E V|)\end{array}$ & P Values \\
\hline $\begin{array}{l}\left.\text { Effectiveness of internal control_( } X_{1}\right)_{-}-> \\
\text {Budgetary_Discipline_( } Y)\end{array}$ & $-0,477$ & $-0,490$ & 0,264 & 1,811 & 0,071 \\
\hline $\begin{array}{l}\left.\text { Ethic_( } X_{3}\right)_{-}>>\text {Budgetary_Discipline_( } Y \\
{ }_{-}\end{array}$ & 0,306 & 0,321 & 0,123 & 2,487 & 0,013 \\
\hline $\begin{array}{l}\left.\text { Good Governance_( } X_{2}\right)_{-}{ }^{->} \\
\text {Budgetary_Discipline_( } Y)_{-}\end{array}$ & 0,988 & 1,000 & 0,237 & 4,168 & 0,000 \\
\hline
\end{tabular}

Source: Author's Processed Data (2019)

The relationship between variables can be said to be significant if it has a t-statistic value greater than 1.96 [35]. So from table 7 it can be concluded that good governance and the quality of accounting information significantly influence budgetary discipline while the effectiveness of internal control does not affect budgetary discipline.

\section{Hypothesis Test Results}

As shown in the above table, the path coefficient obtained for the internal control effectiveness variable is -0.477 . Referring to the book Hair [35] regarding the path coefficient of this number is less than 1, it can be stated that the variable effectiveness of internal control has a negative effect on budgetary discipline.

With the t-value for the variable effectiveness of internal control amounting to 1.81. This figure is below the t-table value of 1.96 which states that the effectiveness of internal control does not significantly influence the budgetary discipline variable. 
While the path coefficient for the good governance variable is 0.988 . Referring to the book Hair [35] regarding the path coefficient of this number approaching 1 , it can be stated that the effectiveness of internal control variables has a positive effect on budgetary discipline. With the t-value for the good governance variable of 2.487 this number is above the $t-$ table value of 1.96 which states that the good governance variable has a significant effect on the budgetary discipline variable.

While the ethical path coefficient is 0.306 and the $\mathrm{t}$ value is 2.487 which is greater than 1.96 which states that ethic has a significant positive effect on budgetary discipline.

\section{DISCUSSION}

The results of the first hypothesis testing show that the internal control effectiveness variable has a negative and insignificant effect on the budgetary discipline variable by showing that it is significant at the 5\% level using the structural relationship in Hair's book [35]. The results of this hypothesis test are in accordance with previous studies conducted by Ramdany et al. [7] With the title "Effectiveness of Internal Control, Good Governance, and Accounting Information Quality of Budgetary Discipline" where the results of the study have the results of the effectiveness of internal controls that are significantly negative towards budgetary discipline.

Overall, the implementation of the Effectiveness of Internal Control in manufacturing companies in the KIIC Industrial Estate Karawang, West Java is quite good but not yet optimal due to poor implementation of work procedures even though the SOP has been implemented. Based on an internal control effectiveness questionnaire according to the Committee of Sponsoring Organizations of The Tradeway Commission (COSO) [36] that discusses the Standard Operating Procedure (SOP), the implementation of work procedures on SOPs in manufacturing companies that are not good, one of which is caused by the demands of the company's production targets very large manufacturing. Very large production target demands cannot be achieved if the implementation of work procedures does not comply with the overall SOP rules. Because, many processes are needed to run production according to work procedures if based on SOP.

The results of the second hypothesis testing show that the good governance variable has a positive and significant effect on the budgetary discipline variable by showing that it is significant at the $5 \%$ level using the structural relationship in the book Hair [35]. The results of testing this hypothesis are supported by previous research conducted by Ben-Caleb Egbide \& Godwyns Ade 'Agbude [37] with the title "Good
Budgeting and Good Governance: A Comparative Disclosure" where the results of the study show that good governance has a relationship with good budgeting, because good governance both must apply effectiveness, efficiency, transparency, accountability and fairness.

Overall, the implementation of good governance in manufacturing companies in the KIIC Karawang Industrial Estate, West Java is quite good and optimal. This can be seen from the implementation of the five principles of good governance carried out by all employees in the company. Based on a questionnaire according to the Chartered Institute of Public Finance and Accountancy (CIPFA) [23], the five principles include the principles of transparency, accountability, responsibility, independence and fairness. The implementation of the five principles can be seen from a good work culture, good company efficiency, a good decision making process, employees who are motivated because of the reward system so as to increase company productivity. Because of this, the value of the company in the eyes of investors can also increase because they believe that the company where they invest is very good management with proven investors and increasing the level of production which is increasing due to the large demand.

The results of the third hypothesis testing show that the Ethic variable has a positive and significant effect on the budgetary discipline variable by showing that it is significant at the $5 \%$ level using structural relationships and the results of testing this hypothesis are supported by previous research conducted by Hosmer and Kiewitz [26] Governance company and Ethics conducted by the company to all stakeholders will produce a positive organization in a strategic position and financial benefits. In line with the research of Festus and Temitope [4] which states that ethics greatly affects the quality of financial statements so that companies with high ethics will provide transparent financial reports. Overall, the implementation of ethics in manufacturing companies in the Karawang KIIC Industrial Estate, West Java has been very good and optimal can be seen from the good ethics of the company. This can be seen based on a questionnaire according to Forsyth [38,39] that discusses ethics in companies assessing ethics in the company KIIC industrial area has a high value in the application of ethics.

\section{ACKNOWLEDGMENT}

This study support by the Faculty of Economic and Business and Research Center of Mercu Buana University. I'm grateful for the supported from Dean, Rector Research Center team and especially the respondent in this study. 


\section{REFERENCES}

1. Choiriah. (2019.a). Effect Of Internal Audit, Supply Chain Management, And Knowledge Management On Total Quality Management, International Journal Of Economics,Business and Management Research, 3 (6);7-14

2. Nengzih. (2014). Corporate Governance, Internal Control And Voluntary Disclosures Of Environmental Accounting To Company Performance : Evidence From Hospital Industries In Indonesia, Research Journal of Finance and Accounting.5(22): 134-145

3. Ridwan, M., \& Putra, W. E. (2016). Pengaruh Komitmen Organisasi, Gaya Kepemimpinan dan Struktur Organisasi terhadap Hubungan antara Partisipasi Anggaran dengan Kinerja Manajerial (Studi pada Rumah Sakit Swasta di Kota Jambi). Jurnal Penelitian Universitas Jambi: Seri Humaniora, 18(1).

4. Adegbie, F. F., \& Temitope, F. E. (2016). Ethics, Corporate Governance and Financial Reporting in the Nigerian Banking Industry: Global Role of International Financial Reporting Standards. Accounting and Finance Research, 5(1), 50-63.

5. Hansen, Don, R., Mowen, Maryanne, M., \& Heitger, Dan, L. (2017). Dasar-dasar Akuntansi Manajerial (5 ${ }^{\text {th }}$ ed.). Jakarta: Salemba Empat.

6. Lubis, Abu, S. (2011). Disiplin Adalah Bagian dari Kemajuan.

http://www.bppk.kemenkeu.go.id/publikasi/artikel

7. Ramdany., Yadiati, Winwin., Suharman, Harry., \& Sofia K, Poppy. (2017). Effectiveness Of Internal Control, Good Governance, And Accounting Information Quality on Budgetary Discipline. International Journal of Business, Economics, and Law, 12(1), 62-70.

8. Choiriah, S. (2019). Effect of Internal Control Systems, Information Asymmetry and Environmental Uncertainty on Budgetary Slack.

9. Choiriah, S. (2019). Effect of Internal Control Systems, Information Asymmetry and Environmental Uncertainty on Budgetary Slack.

10. Dewi, N. P. W. G. P., \& Yadnyana, I. K. (2015). Evaluasi efektivitas pengendalian internal: studi kasus pada pt hutama karya (persero). E-Jurnal Akuntansi, 265-279.

11. Triadi, A. L., \& Suputra, I. D. (2016). Pengaruh Pengendalian Intern Dan Penerapan Prinsip-prinsip Good Corporate Governance Terhadap Kinerja Manajerial. E-Jurnal Akuntansi, 895-920.

12. Berle, A., \& Means, G. (1932). The Modern Corporation and Private Property Macmillan. New York, 2(3), 45-53.

13. Daft, R. L. (2001). Essentials of organization theory and design. South Western Educational Publishing.

14. Baumann, M. D., Kang, C. E., Stanwick, J. C., Wang, Y., Kim, H., Lapitsky, Y., \& Shoichet, M.
S. (2009). An injectable drug delivery platform for sustained combination therapy. Journal of Controlled Release, 138(3), 205-213.

15. Sexty, R. W. (2011). Canadian business and society: Ethics \& responsibilities. McGraw-Hill Ryerson.

16. Subkhi, A., \& Mohammad, J. (2013). Pengantar Teori \& Perilaku Organisasi. Jakarta: Prestasi Pustaka.

17. Mardiasmo. (2016). Akuntansi Sektor Publik. Jakarta: Edisi Empat.

18. Comittee of Sponsoring Organizations of The Tradeway Comission (COSO). (2013). Internal Control-Integrated Framework. Excecutive Summary. USA.

19. Reeve, J.M.,Waren,C.S., Jonathan, E.D., Ersa, T.W.,Gatot, S., Amir, A.J. \& Chaerul, D.D. (2013). Pengantar Akuntansi-Adaptasi Indonesia. Jakarta: Salemba Empat.

20. Horák. R., Klára, Š. (2014). Ethics and the Financial and Budgetary Discipline in the Ministry of Defence. Journal of Modern Accounting and Auditing, 10(2), 182-190.

21. Horák, R., \& Simackova, K. (2014). Ethics and the Financial and Budgetary Discipline in the Ministry of Defence. Journal of Modern Accounting and Auditing, 10(2), 201.

22. Agoes, S., \& Ardana, I. C. (2009). Etika bisnis dan profesi: tantangan membangun manusia seutuhnya. Penerbit Salemba.

23. Chartered Institute of Public Finance and Accountancy (CIPFA). (2014). International Framework: Good Governance in The Public Sector. IFAC \& CIPFA

24. Frostenson, M., Helin, S., \& Sandström, J. (2011). Organising corporate responsibility communication through filtration: A study of web communication patterns in Swedish retail. Journal of Business Ethics, 100(1), 31-43.

25. Fraedrich, J. P., \& Ferrell, O. C. (1992). The impact of perceived risk and moral philosophy type on ethical decision making in business organizations. Journal of Business Research, 24(4), 283-295.

26. Hosmer, L. T., \& Kiewitz, C. (2005). Organizational justice: A behavioral science concept with critical implications for business ethics and stakeholder theory. Business Ethics Quarterly, 15(1), 67-91.

27. Umar, H. (2011). Manajemen Keuangan dan Akuntansi Pemerintah. Cibubur: Pelangi Nusantara.

28. Robbins, Stephen, P., \& Mary Coulter. (2014). Management. $\quad\left(9^{\text {th }}\right.$ ed.). England: Pearson Education.

29. Nicolae, P. V. (2013). The Financial And Budgetary Discipline In Romania-The Arrears Of The Local Public Authorities. Annals-Economy Series, 2, 221-226. 
30. Wren, Daniel, A., \& Arthur, G. Bedeian. (2009). The Evolution of Management Thought. Sixth Edition. USA: John Wiley \& Sons

31. Irons, John, S. (2004). Fiscal Responsibility and Budget Discipline. Center for American Progress. USA. Website https://www.americanprogress.org

32. Tommasi, K., \& Shah, A. (Ed.). (2007). Budgeting and Budgetary Institutions. World Bank Publications.

33. Valentine, S., Godkin, L., \& Lucero, M. (2002). Ethical context, organizational commitment, and person-organization fit. Journal of Business Ethics, 41(4), 349-360.

34. Valentine, S., Godkin, L., \& Lucero, M. (2002). Ethical context, organizational commitment, and person-organization fit. Journal of Business Ethics, 41(4), 349-360.

35. Hair, Joseph, F.,Hult, G. Thomas, M., Ringle, Christian M., Sarstedt, M. (2014). A Primer on
Partial Least Squares Structural Equation Modeling (PLS-SEM). USA: SAGE Publications, Inc.

36. Comittee of Sponsoring Organizations of The Tradeway Comission (COSO). (2013). Internal Control-Integrated Framework. Durham.

37. Egbide, Ben-Caleb., \& Agbude, Godwyn's Ade. (2013). Good Budgeting and Good Governance: A Comparative Disclosure. Journal the Public Administration and Social Politics Review, 2(9); 49-59.

38. Forsyth, D. R. (1981). Moral judgment: The influence of ethical ideology. Personality and Social Psychology Bulletin, 7(2), 218-223.

39. Ruffner, M., \& Sevilla, J. (2005). Public Sector Modernisation. OECD Journal on Budgeting, 4(2), 123-141. 